Article

\title{
Good Idea But Not Here! A Pilot Study of Swedish Tourism Stakeholders' Perceptions of Halal Tourism
}

\author{
Saeid Abbasian
}

check for updates

Citation: Abbasian, S. Good Idea But Not Here! A Pilot Study of Swedish Tourism Stakeholders' Perceptions of Halal Tourism. Sustainability 2021, 13, 2646. https://doi.org/10.3390/ su13052646

Academic Editor: James Kennell

Received: 17 January 2021

Accepted: 24 February 2021

Published: 2 March 2021

Publisher's Note: MDPI stays neutral with regard to jurisdictional claims in published maps and institutional affiliations.

Copyright: (C) 2021 by the author Licensee MDPI, Basel, Switzerland. This article is an open access article distributed under the terms and conditions of the Creative Commons Attribution (CC BY) license (https:/ / creativecommons.org/licenses/by/ $4.0 /)$.
Department of Environmental Science and Tourism Studies, Södertörn University, 14189 Huddinge, Sweden; saeid.abbasian@sh.se

\begin{abstract}
The following study is the first Swedish study on Halal tourism in Sweden. The purpose of this exploratory research is to get insight into the perception of Halal tourism in Sweden among representatives of tourism stakeholders. The overall methodology approach in this research is qualitative, consisting of 25 qualitative questionnaires, 21 short letters, four follow-up interviews, and a web observation, and content analysis was employed. The results indicate that there is a low knowledge of Halal tourism in Sweden including Swedish tourism industry. The concept is very challenging, and profits are low. It might result in problem scenarios such as detrimental effects on non-Halal tourism, cultural difficulties and increased risk of xenophobia, anti-Islamism, and tension in the society. There is low interest for Sweden among Muslim tourists as the interest and priority for Halal tourism is rather low from Swedish tourism industry. Despite Halal tourism's importance internationally, these representatives are rather cautious and doubtful about promotion of Sweden towards this niche. Still, a majority seems to be positive to a lighter version of Muslim-friendly tourism with secular/moderate Muslims as a target group.
\end{abstract}

Keywords: Halal tourism; Sweden; secularism; adaptation; values; gender equality; Muslimfriendly tourism

\section{Introduction}

Halal tourism has been a new topic in tourism research for two decades due to its growing market [1], especially among wealthier Muslim nations [2], and many countries want a share of this market [3,4]. Authors (e.g., [5]) consider the emergence of Halal tourism products in the light of globalization era and its cosmopolitan culture. Some Islamic countries like Malaysia, Indonesia and Turkey are both among leading suppliers of Halal tourism (see e.g., [6]) and suppliers of research on it. Nevertheless, Halal tourism can also be provided by non-Muslim countries and studied by scholars in these countries. For example, the first international conference on Halal tourism was held in Spain [7].

Islam with 1.9 billion formally registered Muslims is the second largest religion in the world after Christianity [8]. Many countries either have a majority or a large number of Muslims among their population [9] and as clear by World Bank's statistics, they represent both rich nations with a high rate of BNP/GDP (Brutto National Product per capita or Gross Domestic Product per capita), and poor nations [10]. Statistical sources (e.g., [8]) estimate that a considerable minority of these inhabitants either are atheists or nonpracticing religion. If only 200 million of the practicing Muslims have a purchasing power corresponding to the European middle class, and they are willing to pay more to receive Halal service when they are abroad, it is worth doing research on it for Sweden.

In contrast to Vargas-Sanchez and Moral-Moral [11], the research on Halal tourism is rather widespread mostly by authors from Islamic countries with focus on these countries, whilst research on non-Muslim countries has been less visible. Halal tourism's potential has been studied earlier in few non-Muslim countries (e.g., [12-20]) but not in Sweden, except limitedly by Hall [21]. A search in Google and in Swedish Diva portal in July 2020 
showed that there have been no debates in major Swedish media on promoting Sweden for Halal tourism and no research on it has been conducted by Swedish scholars. Still, the term and the Halal tourism concept was discussed initially in 2018 by some social media forums (e.g., [22,23]). Additionally, a search in Google scholar showed that there is lack of focus on stakeholders' perspectives in the existing global research.

Hence, the purpose of this exploratory research is to get insight into the perception of Halal tourism in Sweden among representatives of tourism stakeholders, their knowledge level of the issue, and what ideas they have about a promotion of Sweden as a Halal tourism destination. The overall research questions of this paper are following:

(1) What knowledge is there in Sweden, especially in the tourism industry, about Halal tourism?

(2) How do tourism stakeholders perceive a possible marketing of Sweden as a Halal tourism destination as well as opportunities and challenges that exist in this regard?

\section{Research Context}

Although Sweden is known as one of the most secular countries in the world, many religious Christian Lutheran traditions are preserved and respected here as aspects of cultural heritage [24]. Sweden is also a multicultural society with over $25 \%$ of inhabitants with immigrant origin. A considerable part of this population is immigrant and refugee groups with roots in Muslim countries [25]. There are large variations between these groups in their belief or practice of religion in everyday life, their acceptance of modern values, and overall integration into the Swedish society. The Swedish political climate has been rather fragile since 2010 and from that year only minority governments have been governing. At the same time, right-wing extremist and anti-immigrant voices have taken more place in everyday political debates. Despite it, according to the National Swedish Institute, Sweden still has a good reputation in the world [26]. Since a couple of decades, Swedes are familiar with Halal food products that have been on shelves in grocery stores. The Swedish word "Halalturism" was registered in the Swedish Language Council's (Språkrådet) yearly updated list of new terms in 2017 [27].

These are perhaps good preconditions to marketing Sweden as a Halal tourism destination, but Sweden is not among the top European destinations for Muslim tourists [28]. The number of international guest nights in Sweden between 2010 and 2019 increased from 12.8 million to 17.4 million among the 33 largest nations mostly coming from Western countries. Turkey as the only Muslim nation in this statistic with 41,000 guest nights in 2019 is far behind other nations, especially behind Norway in the top with 3.5 million guest nights [29]. According to Swedish National Agency for Regional Growth (Tillväxtverket), the tourism industry stands for only $2.6 \%$ of the BNP and there is potential for more share for international tourism [30]. Halal tourism might can partially help in this issue; investment in this niche may give a new tourism attribute to Sweden as a destination and might attract more Muslim tourists to Sweden.

\section{Literature Review}

\subsection{Definition and Attributes}

Halal tourism, in similarity with some other types of tourism concepts such as Kosher tourism, vegetarian/vegan tourism or eco/sustainable tourism can roughly be defined as ethical-related or morality-related tourism in the first place. Still, in similarity with the two first but in difference with the latter, Halal tourism has a clear link to religious belief concerning food consumption during travel. Kosher tourism as Jewish religious believers' way of tourism mostly emphasizes on food preferences and prohibitions [31,32]. The same is applied for tourists with Hinduism or Buddhism beliefs that consume vegan food [33] in accordance with their religions, even though veganism nowadays is also an ideological convincement as well. Eco/Sustainable tourism, in opposite to all of them, can be linked to ideological belief in the first place [33] and not necessarily linked to food preferences or prohibitions based on religious convincement. However, Kosher tourism and Halal 
tourism show much more similarities with each other in practice than with the two other types of tourism. They have long lists of strict rules that emphasize what to eat and drink vice versa during the travel. Some known common examples between Muslims' Halal and Jews' Kosher dietaries are the prohibition of pork and strict rules of animal slaughter. Other common examples are restrictions on some types of fish and shellfish among both groups of believers [31,32].

Halal tourism, nevertheless, is more complicated than what one can imagine (see e.g., [34]) and it is not limited to food consumption. It is a lifestyle for many people and not only about Muslims' travel to other countries in which some Islamic rules are considered [35,36]. Halal tourism and other similar types of tourism i.e., religious tourism, Islamic tourism, spiritual tourism, Muslim-friendly tourism, and Sharia tourism have been studied in a rank of earlier research by scholars from different disciplines (see e.g., [3,37]).

Halal tourism should not be mixed-up with religious tourism since the latter means visiting religious destinations [38-40]. The term Islamic tourism is used by scholars almost as synonym to Halal tourism (e.g., [3,41-43]) but there is a distinction between them. Authors (e.g., [3]) talk about a difference based on intention and motivation. Islamic tourism means tourism with wider regard to Sharia law and Islamic attributes such as belief, faith, values, principles, participation, Muslim destination, products and services, and dimensions $[39,44,45]$. Halal means something that is permitted according to Sharia rules [46] and Halal tourism means providing Muslim travelers permissible service and products in accordance with Islamic teaching even in a non-Muslim country [46,47]. The fact that Halal products and services are primarily designed for Muslim tourists does not necessarily mean that non-Muslims are not allowed to use them. In contrary, these products may also be demanded by non-Muslims in some extent [48]. However, different actors in academia, media and industry use different terms to mean almost the same thing (see e.g., $[49,50]$ ) which is not always easy to understand.

Halal tourism can roughly be defined as tourism by Muslim and non-Muslim travelers to both Muslim and non-Muslim countries where Islamic compliant services and products are provided to them. That includes Halal hotels/resorts, Halal restaurants, and Halal trips [46]. El-Gohary [39] gives examples of many detailed requirements for Halal hotels such as female and male staff for different genders of customers, Quran and praying mats in each room, dressing codes for the staff, etc., that need to be fulfilled. These criteria might be so demanding for non-Muslim or secular countries that they choose to adapt only a part of their services in some extent and call it Muslim-friendly. Here, prayer rooms at airports, Halal food at restaurants, selected hotels offering Halal food without alcohol and pork but following Islamic slaughter rules, with gender-divided prayer rooms, removing provocative pictures and paintings, carefully selected TV channels, are among the examples $[46,51,52]$. A complete Halal Holiday means that hotels and resorts offer all such services but with totally gender-divided activities, spaces and facilities [46,51,52].

\subsection{Impact}

Impact studies, that mainly touch economic and cultural effects of tourism, include two important parts in a win-win situation: tourists but also host destinations, attractions or businesses that serve the tourists. Halal tourism is generally about tourists' needs for a certain type of service, sometimes multifaceted needs, that must be fulfilled $[2,16,52,53]$. Especially in non-Muslim countries it can create a sense of positive ambience with tourists and a positive intentional behavior in term of purchase of Halal products [54]. Nevertheless, according to Elaziz and Kurt [55], consumer behavior of Halal tourists in terms of vacation is almost the same the non-Halal tourists' behavioral patterns. Halal tourism creates somehow a sort of cultural encounter between tourists and their hosts [56]. The concept may be of such economic importance that regions, countries, hotels, and hoteliers specialize themselves for Halal tourism to achieve regional development $[51,57,58]$ while other regions start programs to promote it [59] or study the preconditions for such development in the future $[60,61]$. Nevertheless, Halal tourism is not limited to a region or a resort but in 
some cases, it can also be applied for restaurants in the city areas [35] or for a geographically delimited park in a nature tourism [62].

Tourists that get their needs of Halal service and products fulfilled, get added value for their visits of businesses, destinations and attractions and that might lead to their positive experiences and total satisfaction [63-69]. That, in turn, results in word of mouth marketing, good image, and more tourists for the destination in issue [70], and the destination in issue becomes a brand both for Muslims and non-Muslim tourists [69,71].

\subsection{Challenges}

Halal tourism, despite its profitability, is not an easy task but complicated such that really challenges a destination [72], especially in non-Muslim countries [46]. For a Halal tourism destination, it is very important to find balance between the needs of Halal tourists and non-Halal tourists with carefully considering both attributes [73-76]. Other important challenges are finding right geographic markets and establishing a network [46]. It requires, therefore, careful planning, especially for a non-Muslim country that might market itself for this tourism type for first time. Even, the moderate Muslim-friendly version of the concept with so many details included can be a dilemma and costly project for businesses in a Muslim country [77].

Some authors (e.g., [41]) talk about a base of intellectual and spiritual capital to start a destination development project with Halal concept. That might be right to some extent since Halal tourism cannot be just provided to potential tourists through facilities and products. Like other types of tourism, personnel need to attend special education [78] and hotels, resorts, and restaurants need to fulfil important criteria, get certificates, and adjust their services to the customers' requirements [79-81]. Other authors (e.g., [82,83]) talk about Halal logistics worldwide and Halal tourism's own supply chain that is extended in the world. By this, it means that new destinations with Halal concept need to be connected to this network.

\subsection{Research Synthesis}

A new idea of destination development can be studied with support from Freeman's [84] classic stakeholders' theory in business administration; a theory that later was developed by him several times (e.g., [85]) but also was applied in other disciplines including tourism and event studies. The theory explains that there are many actors (groups and individuals) that are linked to corporations/organizations; they are both affected by corporations and their decisions but also affect these corporations and their decisions. The theory also emphasizes that the corporations should create added value for all these actors in their long-term and strategic management.

In accordance with stakeholder's theory in tourism context, a new path of destination development needs to be firstly discussed with the most important tourism actors who have knowledge of the industry and who deal with tourism issues daily [86-89]. These different actors (institutions, organizations, enterprises, groups of people), or individuals representing them in a specific destination/country are affected positively or negatively by the national or local tourism industry $[87,90,91]$. Hence, the attitudes and perceptions of these actors are important for an eventual tourism development there since they are considered to start the development [92,93]. With this point of departure, it is important to catch what knowledge, ideas and perceptions these Swedish representatives of tourism stakeholders have on Halal tourism concept and its development in Sweden.

\section{Methodology and Data Collection Procedure}

The following research is an exploratory pilot study since the topic has not been studied earlier in Sweden. This study is interested in words, perceptions and insights rather than in large figures or numbers that are applied in quantitative research [94]. Therefore, to look for answers for the overall research questions in this study, the overall methodology approach in this research is qualitative based on triangulation since data comes from 
four different sources (see Figure 1). Triangulation that is used both in qualitative and quantitative research in social sciences and natural sciences, helps to get stronger data, increased validity and better outcome $[95,96]$.

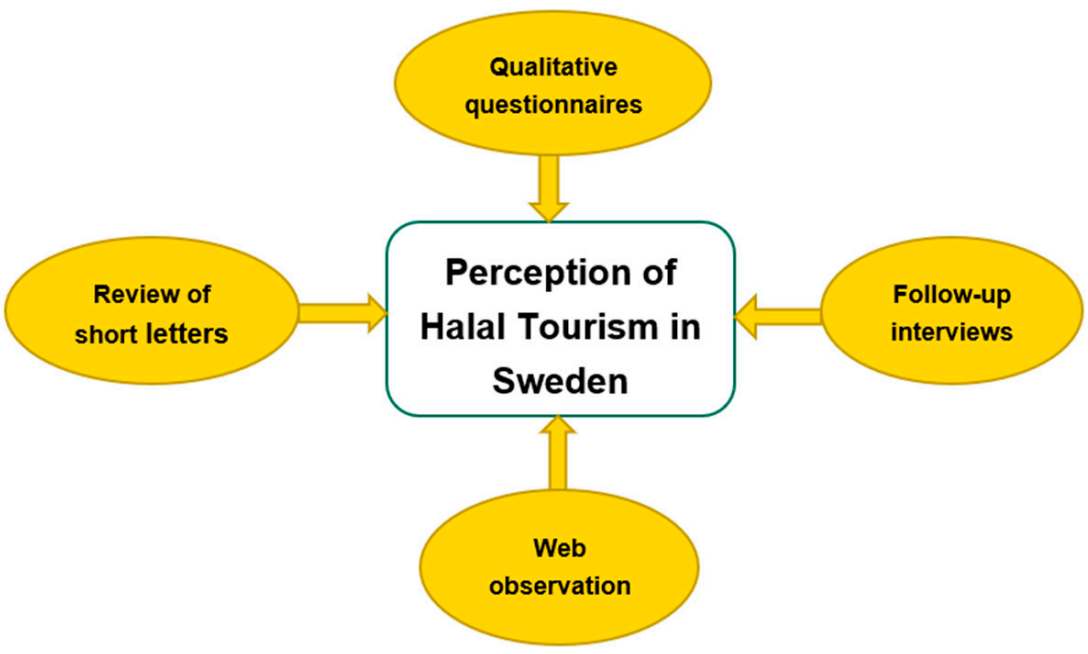

Figure 1. Research design based on triangulation.

Qualitative research in Social Sciences, according to Flick [97], facilitates to understand, describe and explain social phenomena in our surrounding world through analyzing individual or group experiences, through analyzing interactions and communications, and through analyzing documents. Furthermore, Kvale [98] states that one of the most important tools in qualitative research is purely qualitative interviews (i.e., focus group interviews, or face-to-face interviews) that need to be well-prepared but also well-analyzed afterwards. In a later work, that is critical to positivism and quantification, Kvale [99] points out some ethical dilemmas that a qualitative social scientist faces in her/his work during data collection but also during interpretation of the results and analysis.

In contrast to Kvale [98] and Flick [97] that only recognize conversation-based interviews as qualitative interviews, the new generation of scientists do also accept email interviews and qualitative questionnaires as qualitative interviews. The following research has not had the possibility to use purely qualitative interviews as recommended by Kvale $[98,99]$ but a qualitative questionnaire as a substitute to it. Although many scholars believe that questionnaires (including email attached questionnaires) are quantitative research tools, it is not so in practice. Questionnaires can be used both in quantitative, qualitative, and a mixed method research depending on how the questions are designed [100-102]. If the questions have a close-ended/structured form, then the questionnaire is quantitative while if the questions are designed in open-ended/unstructured/semistructured manner the questionnaire is qualitative [100-102]. This study has an inductive approach which means that data was collected first and a connection to earlier research was sought afterwards $[94,103]$. The empirical data in this study, in accordance with triangulation, comes from the following sources.

1. Between June 2018 and June 2020, a questionnaire was sent through email (as an attached Worddocument) out to 258 persons in government, organizations and enterprises with a connection to the Swedish tourism industry. The reason behind this variation of workplaces was to get a broader perspective, and this method was chosen because of the ease of the method and its time and cost-effectiveness. The questionnaire contained 15 semistructured questions; five questions on demographic/background issues (Table 1) and the rest were core questions that required explanations and justifications. In the questionnaire the author gave initially a basic definition of Halal tourism, namely absence of gambling, alcohol and pork in the service, to facilitate for the interviewees. Ultimately, and after four reminders, only 
25 persons sent completed questionnaires. With some exceptions, most respondents gave answers to all questions.

Table 1. General information on the interviewees.

\begin{tabular}{|c|c|}
\hline Gender & 13 men, 12 women \\
\hline Age & Between 26 and 71 years old. Average 44 \\
\hline \multirow{7}{*}{ Workplaces } & 6 hotels and hostels \\
\hline & 3 museums \\
\hline & 5 tourism consulting/PR companies/marketing \\
\hline & 2 governmental authorities \\
\hline & 3 municipal or regional tourism bureaus \\
\hline & $\begin{array}{l}1 \text { destination management company, } 1 \text { sale agency, } 1 \text { amusement park, } \\
1 \text { tour operator, } 1 \text { cruising company }\end{array}$ \\
\hline & 1 did not answer \\
\hline \multirow{7}{*}{ Position } & 8 managers/section managers \\
\hline & 4 owners \\
\hline & $5 \mathrm{CEOs}$ \\
\hline & 2 communicators \\
\hline & 2 receptionists \\
\hline & 1 analyst, 1 international marketing officer, 1 trainee \\
\hline & 1 did not answer \\
\hline $\begin{array}{l}\text { Work experience in } \\
\text { tourism industry }\end{array}$ & Between 1 and 45 years. Average 21 years \\
\hline
\end{tabular}

2. The author also received 21 letters from the email recipients (henceforth recipients) who reasoned why they would not participate. Still, the author chose to include these letters in the analysis since they contained partly valuable information.

3. A web observation in July 2020 by the author.

4. A follow up interview in autumn 2020 with four of the respondents to get an even deeper insight. These interviews were conducted on Zoom and took $30 \mathrm{~min} / \mathrm{each}$ on average.

The 25 questionnaires constitute the main data sources here while the letters, follow up interviews, and web observation function as complement to them. In accordance with ethical issues all interviewees and recipients were totally anonymized in this research.

\section{Data Analysis}

The analysis method in this paper is content analysis that touches social and human processes and suits interpretation of qualitative data in social sciences. This analysis method looks for themes, patterns, meanings, and assumptions in written documents [104-106]. The analysis approach was interpretative which means that the researcher discovers human actions through texts which in their turn cover layers of meanings/symbol expressions, and both manifest (visible) and latent (underlying) meanings of texts are treated [106].

The author followed the conventional content analysis steps i.e., finding codes and categories of inductive meanings and completing with eventually underlying meanings [106]. The 25 questionnaires, 21 letters and the follow up interviews but also the result of web observation were reviewed many times to get an overall sense of the content. Then, a condensed WORD text (as note page) was created and carefully reviewed several times again to sort i.e., discover codes, patterns, relationships, or differences. The final steps were to collect the essence of the data in some significant patterns and processes, reconnection to earlier research and generalization [106]. Quotations were also used to highlight significant 
results. Despite access to analysis software (Nvivo 12) the author chose to do the analysis manually to get a deeper sense of the content. Concerning the issue of saturation of interview numbers [107] the whole material including letters, web observation and follow-up interviews was assessed by the author to be sufficient for such pilot study. In the analysis, the author chose to focus on general perceptions and not on details such as gender, age, work experience, position, or subindustry of the respondents.

\section{Findings and Analysis}

\subsection{Short Results of the Empirical Data}

The three first qualitative questions to the respondents concerned: How would you define Halal Tourism? What do you know about it? What has been your information channel? Only a minor part of the interviewees had a good grip on which exact dimensions are considered in definition of Halal tourism and had some knowledge of the adaptations required to it. Most of them had mentioned oral sources and Internet as their information source. Regarding Halal tourism's significance for Sweden, a majority thought they may do it even though to a limited extent, while the rest were either doubtful or sceptic. Concerning pros of going after this target group, the majority reported diversification of demand, general increase in demand, cultural exchange, and general benefits to consumers, On the cons, the majority pointed to the association between the concept of Halal to slaughter specifically, extensive adaptation of facilities and activities, cultural costs especially in term of collision with Swedish values such as gender equality, risk for increased stereotypies, prejudice, polarization, and right-wing extremism and to the detrimental effects on other target groups.

To the question whether one should go ahead and pursue this target audience or not, several respondents answered "No" and referred among other things to the costs, that Halal tourism is against Swedish values, it can affect the service for other tourists negatively, the market is not big, destinations in Muslim regions have better conditions, or it is better to attract culture tourists, ecotourists and nature tourists. Several others did agree, partly cautiously, and added under precondition that there is a demand; that this should be done by private enterprises and not by governmental authorities; that it does not adversely affect other tourists and all humans' equal values; and that an analysis is made first. Some other respondents only answered that an analysis must be done firstly. To the question on which markets/nations should be targeted, only a small minority mentioned regions or countries such as Middle East, North Africa, UAE, Qatar, Saudi Arabia, India, Egypt, Malaysia, Indonesia, Kuwait, and Muslim communities in European countries. The rest either emphasized need for market analysis, or reasoned it is about a target group and not markets, or answered that they knew too little about the target group.

On problems that may arise from marketing Sweden as a Halal destination, a majority either mentioned cultural difficulties or feared confused identity, leading to blurred destination image. Several of the interviewees found no problem while the rest either thought further analysis was needed or had no idea or answer. To the question if they were willing to invest in Halal tourism in Sweden, a minority was positive while a majority was not that and among other things referred to economic difficulties such as adaptation costs and low profit; cultural difficulties such as gender divisions; they had low knowledge; or they would prefer nature- or ecotourism. Finally, as to under which conditions they could see Halal tourism being undertaken in Sweden, the majority emphasized on lighter adaptations, cultural interaction and openness, inclusion and respect to humans' equal value, to sustainability and fair trade, to goal-oriented work specially with hotels and restaurants.

The recipients answered in their 21 short letters that they lacked the knowledge or experiences to answer the questionnaire; they were not the right persons to answer; the concept was not felt relevant for Sweden and Swedes; they did not work with incoming tourists but outgoing tourists; the concept was not prioritized in their activity, and they had no time to answer. Some of them also raised critical voices on Halal tourists and their wishes, while one showed curiosity to know more about the concept, and one said that he 
would think of doing investment in his activity if demand for Halal tourism increased in Sweden. One who had been working in convent industry for many years added that she never received any request on dietary need concerning Kosher or Halal food.

The web observation through Google aimed to see how the concept of Halal tourism is mentioned by Swedish media and if there is any debate article on it in major Swedish media. The Swedish word "Halalturism" was typed in the search box and the first 100 relevant hits were examined. Most articles came from social media and there was a variation in content between all hits. A majority of them, however, concerned definition of the term and the news that it was a new word in the Swedish wordlist; several articles were about Halal tourism's significance in other countries, and several others were about the neighboring country, Denmark, and its difficulty to fulfil Halal tourists' needs. In the other words, there was no single debate article on the topic and its significance for Sweden.

One of the respondents in follow-up interviews claimed that Sweden is not attractive for Muslim tourists; the middle class in Muslim countries does not have purchasing power to visit Sweden; if yes, they are one-time travelers and not returning like many Europeans. He wants to see only secular Muslim tourists in Sweden or rather ecotourists, nature tourists, or city tourists that give much more revenue. He added Halal tourism is against Swedish secular values and it is therefore contradictory to promote Sweden for Halal tourism, and investments cannot be justified due to the high costs and low profits. The other interviewees with some slight attitude, in similarity, emphasized that a series of cultural and economic complicities might arise if Sweden becomes promoted as a Halal tourism destination. They still want to find an optimal solution; therefore, they believe that a deep analysis on the society, businesses, and the target group is necessary to do before a promotion. The adaptation costs of facilities, menus and activities can negatively affect hotels and restaurants that earn a lot money from selling alcohol but also non-Halal tourists that consume alcohol and non-Halal food. Although they talk about individuals' free choice, inclusion, tolerance and openness in the society, still they wonder where the limit is when it is difficult to find an optimal supply-demand balance that guarantees individuals' rights, Swedish secular values, diversity, open society and profitability for businesses. They do not exclude risk of increased tension and extremism including protests from animal lovers. They believe it is easier to add Halal food in the menu beside vegetarian and non-Halal food, without excluding alcohol, to satisfy all groups' needs. Two of them who believe that there is interest for Sweden in some Persian Gulf-states suggest that arranging tour packages for their tourists to visit Swedish attractions would be a good idea.

\subsection{Low Knowledge of the Issue}

Most of the interviewees seemed to have a limited knowledge of the issue. This is obvious through answers to several questions where they reasoned that they have limited or no knowledge, it is first time they have heard about the term, and they mentioned oral sources or Internet as information source. Almost the same result is confirmed by the recipients. Still, surprisingly, many of these respondents and recipients have touched, partially or fully, on some other important issues in the investigation such as advantages, problems, challenges, significance, investment, markets, in their questionnaires or letters which show that they still either had a little grip on the issue or perhaps looked urgently for more information to respond to the author. However, both recipients and respondents confirm that there is a low awareness of the issue in Sweden including the Swedish tourism industry. It is not surprising since there is almost no debate in Swedish media on Halal tourism.

\footnotetext{
"I had never heard the expression before I received your email, so I had no definition."

"I, who have been in the industry for 20 years, cannot see that there has been any major discussion on it."
} 


\subsection{Challenging Adaptation}

One word that was frequently expressed by most respondents in answer to several questions is "adaptation". They mean since Halal tourism is oriented towards a totally different kind of tourists compared to non-Halal tourists, this adaptation even in a limited extent is very demanding. Since Sweden is still unfamiliar with this kind of tourism, the first important challenge at national level may be the low awareness or acceptance by the society as whole which requires hard work in the cultural realm, as expressed by many of the respondents.

"I believe that there is a great need to raise awareness and knowledge about Halal tourism in general, in Sweden."

"Disadvantages—negative publicity seen from people's ignorance and prejudices. Controversial for some, I think."

Furthermore, adaptation concerns new investment in marketing that, for many years, has relied on markets among Western countries and new markets like China and India. The concept means partial or full adaptation of hotels, attractions and menus that are originally designed for non-Halal tourism, which requires large investments, resources and changes in the organization and costly educational efforts for the staff.

"The disadvantage is that you need to adapt many businesses for this to become developed."

".... it is difficult to lay prayer rugs in our historic environments ... .... Today we have a lack of space so it can be difficult to find prayer rooms that are available every day ........ Food management is problematic as we still want to offer Swedish food above all ...... It is important to train the staff and ensure that the adaptation works in everyday life."

\subsection{Uncertainty about the Economic Impact}

Concerning significance and benefits of Halal tourism for Sweden, the respondents are divided, even though they all confirm that the market is internationally important. While a narrow majority believes that it might have some significance in economic terms (for example to a limited extent in resorts in the major cities), a considerable minority either is hesitant or believes that the concept has no significance. The same pattern is applied for the issue of benefits that are discussed both in economic and cultural terms such as new revenues, inclusion of new target groups and their needs, cultural encounter, multiculturalism, tolerance, openness, and curiosity for Sweden.

Still, the challenging adaption mentioned above can create a sense of uncertainty about the investments and whether Halal market's profitability can cover them due to its low proportion compared to the non-Halal tourism. Many of them believe also that such adaptation can jeopardize the non-Halal tourism (domestic and international) that already gives high profit. There is no widespread gamble and casino culture in Sweden, but many hotels and their restaurants and bars earn a lot by selling alcohol and Swedish food (including pork) to non-Halal tourists. Thus, the lack of alcohol and pork sales means large loss of revenue for them, a risk they would not think to take.

"I think the adaptation should be in proportion to what you get out of this. If a company must build completely new kitchens, adapt spaces and hire knowledgeable people who will then take care of two groups per year, we may not have used our resources properly."

"If Halal tourism means that no games, alcohol or pork may be served in the presence of these visitors, I think it is very unlikely that anyone in Sweden would see it as business potential to target these customers."

"No, it is unprofitable from the beginning. Partly because of the need for investments in separated bathing facilities, partly because there is no income from alcohol and partly because it is culturally contradictory Swedish values." 


\subsection{Cultural Impact: Scenarios of Fear}

By manifest and latent meaning in the data, it is clear that some future problem scenarios might emerge if Sweden becomes a destination for complete Halal package or moderately Muslim-friendly. At an individual level at hotels/resorts, it restricts non-Halal tourists in their obvious rights to eat and drink what they want and in their use of public spaces (like gender-mixed pools). Furthermore, all these restrictions are against both individual freedoms and gender equality that are emphasized in the Swedish constitution.

"Depending on degree of adaptation, polarization, i.e., the requirements are large enough to influence the requirements of other guests. Absence of pork no problems, games and gambling neither, nor (for me) absence of sales of alcohol. But for example, if other guests are not allowed to use their own wine in their rooms or on the terrace, it can be a problem for me too. Also risk of argument for extremists' mantra of "Islamization"."

"Absolutely, but only to the extent that it does not reduce the quality for the rest of the tourists..."

Fear is reported since most of the interviewees (including those who are positive towards a lighter Muslim-friendly concept-see next section) talk about a collision between Swedish values (e.g., secularism, gender equality, all human's equal value, individual freedoms) and Halal tourism requirements (e.g., gender-divided spaces and slaughter rules of animals, religious attributes in public spaces). Still, at a national level, if such negative issues in a complete Halal concept come up to the surface it may create negative political debates, social tension, and strengthens the right-wing extremists' discourses on Muslim phobia. Words like prejudice, secularism, ethical dilemma, polarization, destructive, deleterious, Islamization, extremists, exclusion, negative publicity, controversies, antagonism, xenophobia, have been among the words that have been mentioned in negation purpose in this regard.

"I think that some ethical dilemmas can arise just in view of ideas about gender equality and the equal value of the genders that are worth considering if one decides to market Halal tourism."

"...., it can easily end up in the teeth of those who have xenophobic views (media and extremist parties)."

“... clashes with our view of gender equality. We are the world's most secular country, we are a leader in LGBTQ issues ..."

"Sometimes there is criticism of both Halal and Kosher slaughter, which is a risk for companies that offer these services (hotels, shipping companies, incoming agencies, etc.)-if any group were to start demonstrating against the phenomenon, for example."

\subsection{A Possible Optimal Balance}

On the other hand, the narrow majority mentioned above, is rather positive to the concept but aware of costs of a complete adaptation, but also a part of those who are rather skeptical somehow support a lighter version of Muslim-friendly tourism in which fundamental needs of both non-Halal tourists and Muslim tourists are satisfied while the business still is profitable. This is a latent meaning that can be interpreted by their answers to several questions and supported by the follow-up interviews. They talk almost similarly about same Swedish values that should be preserved and respected; inclusion, tolerance, openness, cultural encounter, all individuals' equal value, free choice, and absence of gender division. This version is beyond both the complete and the Muslim-friendly versions of Halal tourism. It presupposes that the facility has both ordinary food and Halal food in the range, prayer rooms for Halal tourists, and alcohol sale in the restaurant and minibars in the rooms for non-Halal tourists and excludes gender-divided places. Several of them mention "right way", "right target groups" or "good target groups" or "Svensson Muslims" to target which can be interpreted as meaning that they all mean moderate Muslims with open attitude in this regard. 
"If one is looking for facilities that only strive to receive "Halal guests", it is a boring development, I prefer to create arenas to meet no matter what one wants in his/her glass or on his/her plate-here we try to meet and respect everyone regardless of desire."

"Personally, I think all customers' wishes and needs should be met as far as possible, aslong as it does not "affect" other customers. In other words, it is totally okay to have a prayer room, serve Halal food as a special diet, pick out alcohol from minibars, etc. to individual customers who want this, but I doubt that in Sweden they may invest in special facilities where all guests should have this."

"I guess there is a sliding scale of what needs a "Halal tourist" might have. On one extreme, there are perhaps the more orthodox Muslims who live the Qur'an more profoundly and thus, would have previously described needs for separate beaches, bathing times, etc. On the other hand, I see that there would be a large proportion of "Svensson Muslims" who have a more open attitude to Halal and above all would appreciate, for example, hotel that offer Halal-adapted food and drink, which would make the visit/everyday life easier."

"For Muslim tourists, two basic aspects are particularly concerned: Halal food in restaurants and dignified conditions for religion practice in accordance with the standards ....... Halal tourism is not about "adapting ourselves to receive radical Islamists", it is instead about creating and adapting a range of products and services that considers different cultures."

\subsection{Confusion over Marketing}

As clear by visible and latent meanings in the interviews, letters by recipients, by the web observation and probably by many rejections to participate in the interviews, Halal tourism is a low-prioritized area in the Swedish tourism industry. The concept has not yet been in some national agendas and there has been no systematic market investigation on it, neither by national authorities nor by individual enterprises. On the other hand, the fact that Sweden is not a popular destination among Muslim tourists might contribute to this low interest among Swedish tourism stakeholders. Many of the respondents and recipients confirm that Muslim tourists prefer other countries than Sweden.

"In the overall marketing of Sweden as a destination abroad, we focus on a large group of travelers who are curious about new destinations such as Sweden, primarily in nine countries in the world. Therefore, we do not have any specific knowledge about this area-yet."

"I believe that destinations in Muslim regions have an advantage that can be difficult to compete with and that the target group for various reasons chooses these destinations over, for example, Sweden."

Despite the facts above, there is an expressed interest among many of the respondents and recipients in conducting market research or piloting some projects but here confusion arises. In systematic marketing and market investigations, Swedish authorities (e.g., Visit Sweden) normally use geographical markets (specific countries/nations) while most of these respondents and recipients talk about all Halal tourists as a target group i.e., as if they were a homogenous group. In the other words, there is no clear agreement among the respondents on which markets that should be targeted.

"Do not think markets but target groups-it is more effective that way."

"Halal is not about geography/market but a target group."

In addition, many of the interviewees and recipients welcome initiatives both in marketing and market investigation projects by individual enterprises without involving the authorities. This is somehow contradictory since tourism enterprises normally follow recommendations and guidelines that are given by these authorities. All these circumstances indicate a confusion that exists among these representatives and perhaps among the rest of the industry. 


\section{Discussion and Conclusions}

The purpose of this study was to get insight into the perception of Halal tourism in Sweden among representatives of tourism stakeholders, their knowledge level and their ideas about promotion of Sweden as a Halal tourism destination. It is impossible to draw some far-reaching conclusions based on this pilot study, but the results of the data give some indications that might be applicable for the industry and the society.

A complete Halal tourism $[39,46,51,52,72]$ with so many details, restrictions and adaptation efforts demanded seems to be too challenging and complicated for Swedish tourism stakeholders. There are too many religion-based needs $[2,16,52,53]$ here that cannot be fulfilled in a highly secularized society like Sweden. For many Muslim believers it is not about what to eat and drink during the vacation but a lifestyle $[35,36]$ that Swedish tourism stakeholders are not able to tackle. To find a balance between Halal tourists' needs and non-Halal tourists' needs [73-76] is a task they would not think to take. It is not just about finding a balance between the needs of both tourist groups; it is mostly about how to preserve a secular society that is open, tolerant, and inclusive; without necessarily jeopardizing the equal values of individuals, their freedoms and choices, regardless of their gender, religion, nationality, or cultural/ethnic background. Even, the moderate Muslimfriendly tourism [77] that still contains many details is challenging for such country with strong tradition of secularism.

Based on the stakeholders' theory $[84,85]$, authors [86-89] suggest that a new path of destination development needs to be firstly discussed with the most important tourism actors in the destination who have knowledge of the industry. All interviewees and recipients in this paper are representatives of different tourism stakeholders but not all are necessarily among the most important actors. However, despite large differences in knowledge between these representatives, the majority has a rather low level of awareness of Halal tourism, something they share in common with the whole society including tourism industry. There has been no public debate on the issue which of course is a contributing factor.

Authors' statements on the economic impact of Halal tourism and regional development $[51,57,58]$ seems not to be applied for Sweden according to the data in this paper. These representatives have been generally rather cautious and doubtful on the issue, most probably because the non-Halal tourism is already highly profitable. The doubt and cautiousness also exist because all costly investments, efforts and adaptations in this respect are assessed to not correspond to their economic outcome since it is about very low proportions compared to the non-Halal tourism. The fact that a part of Halal services and products can also be available for non-Halal tourists [48], seems not to interest them either that, in opposite, they believe a complete Halal concept disturbs their activity and worsens the service quality for non-halal tourists. It means the difficulty to find balance between the needs of non-Halal tourists and Halal tourists [73-76] since the latter is considered to give no or low profit but jeopardize the quality of service for the former that gives a high profit. A majority seems to have acceptance for a lighter Muslim-friendly tourism that is targeted to moderate Muslims with open attitude and presupposes that both Halal and non-Halal tourists stay in the hotel where there are prayer rooms, Halal food and drink but also non-Halal food and drink are available. This can also be a solution to the problems that might arise in the cultural realm.

Regarding the positive cultural impact such as cultural encounter between hosts and Muslim tourists [56], despite positive words in the data such as cultural openness in the society and cultural encounter with Muslim tourists, there is a sense of fear that a complete Halal tourism but also Muslim-friendly tourism in Sweden rather creates a series of cultural dilemmas. Complete Halal tourism is perceived to not be consistent with Swedish culture and modern values in the constitution like secularism, gender equality, individual freedoms, humans' equal values, and thereby can impede cultural interactions and come in conflict with both the society and with the non-Halal tourism. Through negative publicity it can strengthen political/social tensions in the society which in the 
last decade has received increasingly strong voices against immigrants and refugees from Muslim countries. It can result in even more polarization and xenophobic views in the society, as indicated by many of the respondents.

Swedes travel a lot including to Muslim countries like Turkey, UAE, and Egypt, and they surely have good intellectual and spiritual capital [41] that is a base for Halal tourism promotion in the country. Additionally, the fact that Sweden, as a multicultural society, has received many immigrants and refugees from Muslim countries during recent decades has certainly contributed to this issue. Despite these facts, there is a confusion among tourism stakeholders' representatives in this research concerning geographic markets [46] that the industry should focus on; while the tourism authorities talk about geographical markets, nations and countries, these representatives talk about target group as if they were homogenous. Nevertheless, it seems that Swedes including actors and employees in the tourism industry are not willing to abandon their established secular values like genderequality or obvious individual freedoms in favor of Halal tourism or Muslim-friendly tourism. The results of this research show that these representatives cannot compromise on these norms and there is an acceptance limit here which is a lighter version of Muslimfriendly tourism. The Swedish Tourism industry needs to increase their share of BNP [30], but Halal tourism and Muslim-friendly tourism seems not to be good way to reach this goal, at least in the short term.

\section{Implications and Limitations}

This research has some implications for Swedish government, for the Swedish tourism industry, but also for Swedish research and academia that has generally neglected the issue so far. Hopefully, the Swedish government, the tourism industry and tourism authorities such as Visit Sweden and Tillväxtverket can get better understanding of the issue through this study if they consider doing an analysis on the concept and its markets in the future. This analysis can be based on preconditions for a lighter Muslim-friendly tourism that has been expressed by most of the respondents. Sweden has a lot of natural and cultural attractions that might be interesting for many Muslim-tourists that come from totally different environments than Sweden. This study may also encourage other Swedish tourism scholars to get involved in the research with new research questions that might have emerged in this paper.

This study had some methodological limitations mostly due to the chosen method (email-questionnaire as main data source) which was not appropriate for this study. The respondents would probably have expressed themselves more openly if they were totally anonymous to the author, and if better formulated questions were asked. A well-prepared triangulation would have been a better method, or better than this, a mixed methods survey online would have been much better to achieve an extended number of respondents anonymously and more generalizable results with both qualitative and quantitative questions. One more limitation concerns the web observation based on Swedish Google that the author discovered afterwards; Google algorithms that have been applied for web observation are significantly affected by the author's characteristics as a computer user. That means that another user might get different results of the web observation. Nevertheless, the author did the same test with four computers outside the university which showed that the hits appeared in a slightly different order but still there was no general debate on "Halalturism" in the major Swedish media among them.

The achieved results in this paper need to be further studied in a much larger sample, with more specific questions and more representatives from Tourism subindustries, preferably with hotel industry that is the most relevant area for such research.

Funding: This research received no external funding. The APC was funded by Södertörn University. Institutional Review Board Statement: Not applicable.

Informed Consent Statement: Not applicable. 


\section{Data Availability Statement: Not applicable.}

Acknowledgments: The author would like to thank all respondents for their valuable information. Additionally, a warm thanks is dedicated to Gustaf Onn and Pouyan Zamani for their valuable comments on the first manuscript.

Conflicts of Interest: The author declares no conflict of interest.

\section{References}

1. Razalli, M.R.; Abdullah, S.; Hasan, M.G. Developing a Model for Islamic Hotels: Evaluating Opportunities and Challenges. In Proceedings of the International Conference on Knowledge, Culture and Society 2012 (ICKCS 2012), Jeju Island, Korea, 29-30 June 2012.

2. Han, H.; Al-Ansi, A.; Olya, H.G.T.; Kim, W. Exploring halal-friendly destination attributes in South Korea: Perceptions and behaviors of Muslim travelers toward a non-Muslim destination. Tour. Manag. 2019, 71, 151-164. [CrossRef]

3. Bogan, E.; Sariisik, M. Halal tourism: Conceptual and practical challenges. J. Islam. Mark. 2019, 10, 87-96. [CrossRef]

4. Samori, Z.; Salleh, N.S.M.D.; Khalid, M.M. Current trends on Halal tourism: Cases on selected Asian countries. Tour. Manag. Perspect. 2016, 19, 131-136. [CrossRef]

5. Ladiqi, S.; Wardhani, B.; Wekke, I.S.; Abdur Rahim, A.F. Globalization and the rise of cosmopolitan shariah: The challenge and opportunity of Halal tourism in Indonesia. Herald NAMSCA 2018, 1, 904-907.

6. Ghazzi, O.A.; Kraidy, M.M. Neo-Ottoman Cool 2: Turkish Nation Branding and Arabic-Language Transnational Broadcasting. Int. J. Commun. 2013, 7, 2341-2360.

7. Spain: Halal Tourism Conference Attracts Hotel Experts. 2014. Available online: https://halalfocus.net/spain-halal-tourismconference-attracts-hotel-experts/ (accessed on 28 July 2020).

8. Religious Composition by Country, 2010-2050. 2020. Available online: https://www.pewforum.org/2015/04/02/religiousprojection-table/2020/number/all/ (accessed on 8 July 2020).

9. Jacob, F. These Are All the World's Major Religions in One Map. 2019. Available online: https://www.weforum.org/agenda/20 19/03/this-is-the-best-and-simplest-world-map-of-religions (accessed on 8 July 2020).

10. BNP Per Invånare. 2020. Available online: https://www.globalis.se/Statistik/BNP-per-invaanare (accessed on 8 July 2020).

11. Vargas-Sanchez, A.; Moral-Moral, M. Halal tourism: State of the art. Tour. Rev. 2018. [CrossRef]

12. Henderson, J.C. Muslim travellers, tourism industry responses and the case of Japan. Tour. Recreat. Res. 2016, 41, 339-347. [CrossRef]

13. Henderson, J.C. Halal food, certification and halal tourism: Insights from Malaysia and Singapore. Tour. Manag. Perspect. 2016, 19, 160-164. [CrossRef]

14. Ahmed, M.J.; Akbaba, A. The potential of Halal Tourism in Ethiopia: Opportunities, Challenges and Prospects. Int. J. Contemp. Tour. Res. 2018, 1, 13-22. [CrossRef]

15. Yasuda, S. Managing Halal Knowledge in Japan: Developing Knowledge Platforms for Halal Tourism in Japan. Asian J. Tour. Res. 2017, 2, 65-83. [CrossRef]

16. Chanin, O.; Sriprasert, P.; Abd Rahman, H.; Don, M.S. Guidelines on Halal Tourism Management in the Andaman Sea Coast of Thailand. J. Econ. Bus. Manag. 2015, 3, 791-794. [CrossRef]

17. Suharko, S.; Khoiriati, S.D.; Krisnajaya, I.M.; Dinarto, D. Institutional conformance of Halal certifi cation organisation in Halal tourism industry: The cases of Indonesia and Thailand. Tour. Rev. 2018, 66, 334-348.

18. Razzaq, S.; Hall, C.M.; Prayag, G. The capacity of New Zealand to accommodate the halal tourism market- Or not. Tour. Manag. Perspect. 2016, 18, 92-97. [CrossRef]

19. Wan-Hassan, W.M.; Awang, K.W. Halal Food in New Zealand Restaurants: An Exploratory Study. Int. J. Econ. Manag. 2009, 3, 385-402.

20. Mutsikiwa, M.; Basera, C.H. The Influence of Socio-cultural Variables on Consumers' Perception of Halal Food Products: A Case of Masvingo Urban, Zimbabwe. Int. J. Bus. Manag. 2012, 7, 112-119. [CrossRef]

21. Hall, M.C. Is Halal the New Nordic Cuisine? The Significance of the Contemporary Globalisation of Foodways for Food Tourism and Hospitality. Extended abstract. In Book of Abstracts, Proceedings of the Tomorrow's Food Travel (TFT) Conference, Gothenburg, Sweden, 8-10 October 2018; University of Gothenburg: Gothenburg, Sweden, 2018.

22. Ehle, D. Halalturism och Kosherturism. 2018. Available online: https://motargument.se/2018/08/07/halalturism-ochkosherturism/ (accessed on 8 July 2020).

23. Lorentz, E. Danmark Rankat Lågt Inom Halalturism-Sverige Toppar Listan i Norden. 2018. Available online: https:// nyheteridag.se/danmark-rankat-lagt-inom-halalturism-sverige-toppar-listan-i-norden/ (accessed on 28 July 2020).

24. Reimers, E. Secularism and Religious Traditions in Nonconfessional Swedish Preschools: Entanglements of Religion and Cultural Heritage. Br. J. Relig. Educ. 2020, 42, 275-284. [CrossRef]

25. Statistics Sweden/SCB. Utrikes Födda Samt Födda i Sverige Med en Eller Två Utrikes Födda Föräldrar Efter Födelseland/Ursprungsland, 31 December 2018, Totalt. 2020. Available online: www.scb.se (accessed on 1 July 2020).

26. Bilden av Sverige Utomlands 2018-Årsrapport Från Svenska Institutet. 2020. Available online: https://si.se/app/uploads/2019 /02/si_rapport_sverigebild_web_low.pdf (accessed on 8 July 2020). 
27. Nyorden 2017: Vad Betyder “Plogga" och “Omakase"? 2017. Available online: https://www.svd.se/nyorden-2017-vad-betyderplogga-och-omakase (accessed on 28 July 2020).

28. France Most Popular European Travel Destination for Muslims. 2014. Available online: https://halalfocus.net/france-mostpopular-european-travel-destination-for-muslims/ (accessed on 28 July 2020).

29. Tillväxtverket. Antal Gästnätter Fördelat efter Hemland/Marknad (Nights Spent and Visitors' Country of Residence). 2020. Available online: https:/ / tillvaxtverket.se/statistik/vara-undersokningar/resultat-fran-turismundersokningar/2020-02-06 -gastnatter-2019.html (accessed on 21 August 2020).

30. Tillväxtverket. Fakta om Svensk Turism 2018; Tillväxtverket: Stockholm, Sweden, 2019; Available online: https: / tillvaxtverket.se/ vara-tjanster/publikationer/publikationer-2019/2019-06-18-fakta-om-svensk-turism-2018.html (accessed on 21 August 2020).

31. Cohen Ioannides, M.W.; Ioannides, D. Global Jewish tourism-Pilgrimages and remembrance. In Tourism, Religion and Spiritual Journeys; Timothy, D.J., Olsen, D.H., Eds.; Routledge: London, UK; New York, NY, USA, 2006; pp. $156-171$.

32. Moira, P.; Mylonopoulos, D.; Vasilopoulou, P. Food Consumption during Vacation: The Case of Kosher Tourism. Int. J. Res. Tour. Hosp. 2015, 1, 9-22.

33. Chieh Lu, A.C.; Gursoy, D.; Del Chiappa, G. The Influence of Materialism on Ecotourism Attitudes and Behaviors. J. Travel Res. 2016, 55, 176-189.

34. Islam, T.; Chandrasekaran, U. Halal Marketing: Growing the Pie. Int. J. Manag. Res. Rev. 2013, 3, 3948.

35. Shaari, J.A.N.; Khalique, M.; Malek, N.I.A. Halal Restaurant: Lifestyle of Muslims in Penang. Int. J. Glob. Bus. 2013, 6, 1-15.

36. Shaari, J.A.N.; Khalique, M.; Aleefah, F. Halal Restaurant: What Makes Muslim In Kuching Confident? J. Econ. Dev. Manag. IT Financ. Mark. 2014, 6, 23-34.

37. Haq, F.; Wong, H.Y. Is spiritual tourism a new strategy for marketing Islam? J. Islam. Mark. 2010, 1, 136-148. [CrossRef]

38. Eid, R. Towards a High-quality Religious Tourism Marketing: The case of Haji Service in Saudi Arabia. Tour. Anal. 2012, 17, 509-522. [CrossRef]

39. El-Gohary, H. Halal tourism, is it really Halal? Tour. Manag. Perspect. 2016, 19, 124-130. [CrossRef]

40. Kana, A.G. Religious Tourism in Iraq, 1996-1998: An Assessment. Int. J. Bus. Soc. Sci. 2011, 2, 12-20.

41. Ariyanto, A.; Chalil, R.D. The Role of Intellectual and Spiritual Capital in Developing Halal Tourism. In Proceedings of the 7th Annual International Conference (AIC) Syiah Kuala University and The 6th International Conference on Multidisciplinary Research (ICMR) in conjunction with the International Conference on Electrical Engineering and Informatics (ICELTICs) 2017, Banda Aceh, Indonesia, 18-20 October 2017.

42. Duman, T. Value of Islamic Tourism Offering: Perspectives from the Turkish Experience. In Proceedings of the World Islamic Tourism Forum (WITF 2011), Kuala Lumpur, Malaysia, 12-13 July 2011.

43. Kovjanic, G. Islamic Tourism as a Factor of the Middle East Regional Development. Turizam 2014, 18, 33-43. [CrossRef]

44. Carboni, M.; Perelli, C.; Sistu, G. Is Islamic tourism a viable option for Tunisian tourism? Insights from Djerba. Tour. Manag. Perspect. 2014, 11, 1-9. [CrossRef]

45. Zamani-Farahani, H.; Henderson, J.C. Islamic tourism and managing tourism development in Islamic societies: The case of Iran and Saudi Arabia. Int. J. Tour. Res. 2010, 12, 79-89. [CrossRef]

46. Battour, M.; Ismail, M.N. Halal Tourism: Concepts, practices, challenges and future. Tour. Manag. Perspect. 2016, 19, 150-154. [CrossRef]

47. Mohsin, A.; Ramli, N.; Alkhulayfi, B.A. Halal Tourism: Emerging opportunities. Tour. Manag. Perspect. 2016, 19, 137-143. [CrossRef]

48. Battour, M.; Hakimian, F.; Ismail, M.; Bogan, E. The perception of non-Muslim tourists towards halal tourism: Evidence from Turkey and Malaysia. J. Islam. Mark. 2018, 9, 823-840. [CrossRef]

49. Khan, F.; Callanan, M. The "Halalification" of tourism. J. Islam. Mark. 2017, 8, 558-577. [CrossRef]

50. Wingett, F.; Turnbull, S. Halal holidays: Exploring expectations of Muslim-friendly holidays. J. Islam. Mark. 2017, 8, 642-655. [CrossRef]

51. Henderson, J.C. Sharia-compliant hotels. Tour. Hosp. Res. 2010, 10, 246-254. [CrossRef]

52. Oktadiana, H.; Pearce, P.L.; Chon, K. Muslim travellers' needs: What don't we know? Tour. Manag. Perspect. 2016, 20, 124-130. [CrossRef]

53. Jafari, J.; Scott, N. Muslim world and its tourism. Ann. Tour. Res. 2014, 44, 1-19. [CrossRef]

54. Jeaheng, Y.; Al-Ansi, A.; Han, H. Halal-friendly hotels: Impact of halal-friendly attributes on guest purchase behaviors in the Thailand hotel industry. J. Travel Tour. Mark. 2019, 36, 729-746. [CrossRef]

55. Elaziz, M.F.; Kurt, A. Religiosity, consumerism and halal tourism: A study of seaside tourism organizations in Turkey. Tourism 2017, 65, 115-128.

56. Ghadami, M. The role of Islam in the tourism industry. Elixir Mgmt. Arts 2012, 52, 11204-11209.

57. Bastman, A. Lombok Islamic Tourism Attractiveness: Non-Moslem Perspectives. Int. J. Supply Chain Manag. 2018, 7, 206-210.

58. Dawood, S.R.S.; Leng, K.S.; Yusof, N. Regional Halal Clusters in the NCER Region: Revisiting the Role of Institutional Thickness. Int. J. Environ. Soc. Space 2014, 2, 47-60.

59. Fithry, S.; Anwar, S. An Evaluation of Halal Tourism Program in East Lombok Regency Using Kirkpatrick's Mode. Sumatra J. Disaster Geogr. Geogr. Educ. 2018, 2, 77-83. [CrossRef] 
60. Moldakhmet, B.; Nassimova, G.; Asan, A.B.A. Islam in Kazakhstan: Modern Trends and Stages of Development. Int. J. Soc. Manag. Econ. Bus. Eng. 2012, 6, 152-155.

61. Gilani, M.K.Z.; Monsef, S.M.S. Strategic Planning for Halal Tourism Development in Gilan Province. Iran. J. Optim. 2017, 9, 49-55.

62. Rhama, B.; Alam, M.D.S. The Implementation of Halal Tourism in Indonesia National Park. In Proceedings of the Advances in Economics, Business and Management Research (AEBMR), International Conference on Administrative Science (ICAS 2017), Makassar, Indonesia, 20-21 November 2017; Volume 43, pp. 48-53.

63. Isa, S.M.; Chin, P.N.; Muhammad, N.U. Muslim tourist perceived value: A study on Malaysia Halal tourism. J. Islam. Mark. 2018, 9, 402-420. [CrossRef]

64. Wardi, Y.; Abror, A.; Trinanda, O. Halal tourism: Antecedent of tourist's satisfaction and word of mouth (WOM). Asia Pac. J. Tour. Res. 2018, 23, 463-472. [CrossRef]

65. Tama, H.A.; Voon, B.H. Components of Customer Emotional Experience with Halal Food Establishments. Procedia Soc. Behav. Sci. 2014, 12, 272-280. [CrossRef]

66. Liu, Y.C.; Li, I.J.; Yen, S.Y.; Sher, P.J. What Makes Muslim Friendly Tourism? An Empirical Study on Destination Image, Tourist Attitude and Travel Intention. Adv. Manag. Appl. Econ. 2018, 8, 27-43.

67. Abror, A.; Wardi, Y.; Trinanda, O.; Patrisia, D. The impact of Halal tourism, customer engagement on satisfaction: Moderating effect of religiosity. Asia Pac. J. Tour. Res. 2019, 24, 633-643. [CrossRef]

68. Battour, M.; Battor, M.; Bhatti, M.A. Islamic attributes of destination: Construct development and measurement validation, and their impact on tourist satisfaction. Int. J. Tour. Res. 2013, 16, 556-564. [CrossRef]

69. Rahman, M.; Moghavvemi, S.; Thirumoorti, T.; Rahman, M.K. The impact of tourists' perceptions on halal tourism destination: A structural model analysis. Tour. Rev. 2020, 75, 575-594. [CrossRef]

70. Al-Ansi, A.; Han, H. Role of halal friendly destination performances, value, satisfaction, and trust in generating destination image and loyalty. J. Destin. Mark. Manag. 2019, 13, 51-60. [CrossRef]

71. Rahman, M.; Rana, M.S.; Hoque, M.N.; Rahman, M.K. Brand perception of halal tourism services and satisfaction: The mediating role of tourists' attitudes. Int. J. Tour. Sci. 2019, 19, 18-37. [CrossRef]

72. Rasul, T. The trends, opportunities and challenges of halal tourism: A systematic literature review. Tour. Recreat. Res. 2019, 44, 434-450. [CrossRef]

73. Battour, M.; Ismail, M.N.; Battour, M. The Impact of Destination Attributes on Muslim Tourist's Choice. Int. J. Tour. Res. 2011, 13, 527-540. [CrossRef]

74. Battour, M.; Ismail, M.N.; Battor, M.; Awais, M. Islamic Tourism: An empirical examination of travel motivation and satisfaction in Malaysia. Curr. Issues Tour. 2017, 20, 50-67. [CrossRef]

75. Rahman, M.K.; Zailani, S. The effectiveness and outcomes of the Muslim-friendly medical tourism supply chain. J. Islam. Mark. 2017, 8, 732-752. [CrossRef]

76. Rahman, M.K.; Zailani, S.; Musa, G. The perceived role of Islamic medical care practice in hospital: The medical doctor's perspective. J. Islam. Mark. 2018, 9, 2-18. [CrossRef]

77. Junaidi, J. Halal-friendly tourism and factors influencing halal tourism. Manag. Sci. Lett. 2020, 10, 1755-1762. [CrossRef]

78. Alina, A.R.; Rafida, A.R.N.; Syamsul, H.K.M.W.; Mashitoh, A.S.; Yusop, M.H.M. The Academia's Multidisciplinary Approaches in Providing Education, Scientific Training and Services to the Malaysian Halal Industry. Middle-East J. Sci. Res. 2013, $13,79-84$.

79. Razalli, M.R.; Abdullah, S.; Yusoff, R.Z. Is Halal Certification Process “Green”? Asian J. Technol. Manag. $2012,5,33-41$.

80. Saad, H.E.; Ali, B.N.; Abdel-Ati, A.M. Sharia-compliant hotels in Egypt: Concept and challenges. Adv. Hosp. Tour. Res. (AHTR) 2014, 2, 1-15.

81. Wimeina, Y.; Wahyuni, D. Identification of Halal Destination Criteria Fulfillment within Padang Beach Area as Tourism Attraction Icon of the City of Padang. In Proceedings of the International Conference of Applied Science on Engineering, Business, Linguistics and Information Technology (ICo-ASCNITech), Padang, Indonesia, 13-15 October 2017; pp. $299-2532$.

82. Talib, M.; Hamid, A.B.; Zulfakar, M.; Jeeva, A. Halal Logistics PEST Analysis: The Malaysia Perspectives. Asian Soc. Sci. 2014, 10, 119-131.

83. Talib, M.S.A.; Rubin, L.; Zenghyi, V.K. Qualitative Research on Critical Issues in Halal Logistics. J. Emerg. Econ. Islam. Res. 2013, 1, 1-20. [CrossRef]

84. Freeman, R.E. Strategic Management: A Stakeholder Approach; Cambridge University Press: Cambridge, UK, 2010.

85. Freeman, R.E.; Harrison, J.S.; Wicks, A.J.; Parmar, B.L.; De Colle, S. Stakeholder Theory-The State of the Art. Acad. Manag. Ann. 2010, 4, 403-445.

86. Presenza, A.; Cipollina, M. Analysing tourism stakeholders' networks. Tour. Rev. 2010, 65, 17-30. [CrossRef]

87. Sheehan, L.R.; Ritchie, J.R.B. Destination stakeholders: Exploring identity and salience. Ann. Tour. Res. 2005, 32, 711-734. [CrossRef]

88. Timur, S.; Getz, D. A network perspective on managing stakeholders for sustainable urban tourism. Int. J. Contemp. Hosp. Manag. 2008, 20, 445-461. [CrossRef]

89. Tuohino, A.; Konu, H. Local stakeholders' views about destination management: Who are leading tourism development? Tour. Rev. 2014, 69, 202-215. [CrossRef]

90. Franch, M.; Martini, U.; Buffa, F. Roles and opinions of primary and secondary stakeholders within community-type destinations. Tour. Rev. 2010, 65, 74-86. [CrossRef] 
91. Komppula, R. The role of different stakeholders in destination development. Tour. Rev. 2016, 71, 67-76. [CrossRef]

92. Laesser, C.; Beritelli, P. St. Gallen consensus on destination management. J. Destin. Mark. Manag. 2013, 2, 46-49. [CrossRef]

93. Strobl, A.; Peters, M. Entrepreneurial reputation in destination networks. Ann. Tour. Res. 2013, 40, 59-82. [CrossRef]

94. Bryman, A. Social Research Methods; Oxford University Press: Oxford, UK, 2015.

95. Kern, F. The Trials and Tribulations of Applied Triangulation: Weighing Different Data Sources. J. Mix. Methods Res. 2018, 12, 166-181. [CrossRef]

96. Bekhet, A.K.; Zauszniewski, J.A. Methodological Triangulation: An Approach to Understanding Data. Nurse Res. 2012, 20, 40-43. [CrossRef]

97. Flick, U. Editorial Introduction. In Doing Interviews—Steinar Kvale; Flick, U., Ed.; The Sage Qualitative Research Kit, Sage Publications: London, UK, 2007; pp. ix-xiii.

98. Kvale, S. Introduction to interview research. In Doing Interviews-Steinar Kvale; Flick, U., Ed.; The Sage Qualitative Research Kit, Sage Publications: London, UK, 2007; pp. 1-10.

99. Kvale, S. Qualitative Inquiry between Scientistic Evidentialism, Ethical Subjectivism and the Free Market. Int. Rev. Qual. Res. 2008, 1, 5-18. [CrossRef]

100. McGuirk, P.; O'Neill, P. Using Questionnaires in Qualitative Human Geography. In Qualitative Research Methods in Human Geography; Hay, I., Ed.; Faculty of Social Sciences-Papers; Oxford University Press: Don Mills, ON, Canada, 2016; pp. 246-273. Available online: https:/ / ro.uow.edu.au/sspapers/2518 (accessed on 6 January 2021).

101. Ishikawa, T. Japanese university students' attitudes towards their English: Open-ended email questionnaire study. In ELF: Pedagogical and Interdisciplinary Perspect; Tsantila, N., Mandalios, J., Ilkos, M., Eds.; Deree-The American College of Greece: Athens, Greece, 2016; pp. 87-94.

102. Murgan, M.G. A Critical Analysis of the Techniques for Data Gathering in Legal Research. J. Soc. Sci. Hum. 2015, 1, $266-274$.

103. Clarke, V.; Braun, V. Thematic analysis. J. Posit. Psychol. 2017, 12, 297-298. [CrossRef]

104. Berg, K.E.; Latin, R.W. Essentials of Research Methods in Health, Physical Education, Exercise Science and Recreation, 3rd ed.; Lippincott, Williams and Wilkins: Philadelphia, PA, USA, 2008.

105. Bogdan, R.C.; Biklen, S.K. Qualitative Research for Education, 5th ed.; Allyn and Bacon: Boston, MA, USA, 2007.

106. Lune, H.; Berg, B.L. Qualitative Research Methods for the Social Sciences, 9th ed.; Pearson: Harlow, UK, 2017.

107. Terry, G.; Hayfield, N.; Clarke, V.; Braun, V. Thematic Analysis. In The Sage Handbook of Qualitative Research in Psychology, 2nd ed.; Willing, C., Stainton-Rogers, W., Eds.; Sage Publications Ltd.: London, UK, 2017. 